International Journal of Current Advanced Research

ISSN: O: 2319-6475, ISSN: P: 2319 - 6505, Impact Factor: SJIF: 5.995

Available Online at www.journalijcar.org

Volume 6; Issue 3; March 2017; Page No. 2987-2991

DOI: http://dx.doi.org/10.24327/ijcar.2017.2991.0161

Research Article

\title{
A SYSTEMATIC REVIEW: THE PREVEIANCE OF PARTIAL EDENTULOURISM IN PATIENTS WITH ECTODERMAL DYSPLASIA
}

\author{
Nur Qistina Binti Ahmad Fauzi., Ashok and Dhanraj
}

Saveetha Dental College and Hospital, 162 PH Road, Chennai-600077

\begin{tabular}{l}
\hline A R T I C L E I N F O \\
\hline Article History: \\
Received $26^{\text {th }}$ December, 2016 \\
Received in revised form $16^{\text {th }}$ January, 2017 \\
Accepted $12^{\text {th }}$ February, 2017 \\
Published online $28^{\text {th }}$ March, 2017 \\
\end{tabular}

Key words:

Partial Edentulourism, Ectodermal Dysplasia

\begin{abstract}
A B S T R A C T
Aim: To compile information regarding how ectodermal dysplasia is managed through various dental treatments.

Materials and Method: A detailed search was performed on articles related to ectodermal dysplasia. Specifically, in this review, it focuses on the treatment plans in children with this disease. A search was performed in the PubMed (Medline) and Web of Science databases to collect relevant information on the restoration of oral function in ED patients using dentures.

Results: 538 in total of related articles and abstracts were obtained from using the electronic search. During the initial screening, 420 articles were excluded. 118 articles were then completely evaluated resulting in only 53 being assesed as it fulfills the inclusion criteria of the systematic review. At the end, only 18 studies were used for assessment.

Conclusion: In a nutshell, the capability of deciding on a treatment for patients that have hypodontia in accordance to the evidence is not yet possible. Although implant therapy for hypodontia patients have a better outcome, when dealing with children, removable partial denture is the most suitable choice.
\end{abstract}

Copyright $\bigcirc 2017$ Nur Qistina Binti Ahmad Fauzi., Ashok and Dhanraj. This is an open access article distributed under the Creative Commons Attribution License, which permits unrestricted use, distribution, and reproduction in any medium, provided the original work is properly cited.

\section{INTRODUCTION}

Ectodermal dysplasia (ED) is most commonly known to be a group of inherited disorders that are characterized with the presence of developmental abnormalities in either two or more of the four existing ectodermal structures; most commonly the teeth, hair, nails, and sweat glands-including other ectodermal structures ${ }^{[1,2]}$. Out of all these ectodermal structures, the human dentition is the most significant criteria taken into consideration for diagnosing ED patients. Ectodermal dysplasia is specifically caused only through genetic anomalies; which is either passed down from parents or caused by mutation of the genes ${ }^{[3]}$. In terms of its classification, it can be either hypohidrotic or hidrotic. Hypohidrotic is mainly characterized by the absence or decrease in sweat glands while hidrotic is characterized by the presence of relatively normal sweat glands ${ }^{[4]}$. Hypohidrotic $\mathrm{ED}$ is the most common form of ED seen in patients. This form of ED generally affects males more while females will only exhibit minor effects ${ }^{[5]}$. Physically, HED patients exhibit common facial characteristics such as frontal bossing, "saddle" nose, maxillary hypoplasia, and hyperkeratotic wrinkles surrounding the eyes (contributing to the similar facial appearance they have) ${ }^{[6,7]}$.

*Corresponding author: Nur Qistina Binti Ahmad Fauzi Saveetha Dental College and Hospital, 162 PH Road, Chennai-600077
HED is the more valuable in the dental community as it predominantly shows more dental anomalies than other symptoms ${ }^{[8]}$. During diagnosis, $80 \%$ will show hypodontia, while some other symptoms include oligodontia (decrease in the number of teeth) with conical teeth, hypohidrosis and hypotrichosis ${ }^{[9]}$. They will also commonly exhibit reduction in salivary secretion, dryness of the oral mucosa and having a hoarse voice ${ }^{[8]}$. When dealing with congenital deformities like oligodontia, the absence of dentition starts at an early stage of life; differing them from other oral problems like caries or periodontitis. One of the main advantage to this is that the patient is well adapted to their defects. Treatment wise, prosthodontic treatments are needed even in early childhood. However, many difficulties are faced during treatment mainly because the teeth are not yet ready to be used as an abutment as the pulp cavity is large. Dentures are also not suitable as the jaw is still in the process of development ${ }^{[10]}$. Overall, there can be primarily four to five treatments available for these patients. Firstly, the option of preserving the primary decidious teeth is normally selected. Secondly, there is an option of tooth transplantation; which helps in the healing of functional periodontium allowing for the mastication and development of the alveolar crest. Thirdly, the preparation of prosthetics can be done; primarily unsplinted overdentures. The fourth option would be the placement of dental implants ${ }^{[11]}$. The main pupose of this study is to provide a 
systematic review of the literature regarding treatments options for patients that have ectodermal dysplasia.

\section{METHODS}

\section{Search strategies}

A search was performed in the PubMed of the US National Library of Medicine to obtain relevant information on the restoration of oral function in ED patients using dentures. The following search for relevant literature were used: (tooth OR teeth OR dental) AND (oligodontia OR ectodermal dysplasia OR hypodontia) AND (rehabilitation OR treatment).

\section{Study inclusion and exclusion criteria}

During the first stage of study selection, the titles and abstracts were screened and evaluated in accordance with the following inclusion criteria:

1. English language;

2. Human clinical studies including case reports, prospective and retrospective studies, and reviews;

3. Studies aimed at investigation specifically of patients that have hypodontia.

During this procedure, the pre-selected publications were then evaluated according to the following exclusion criteria:
2. More than 5 patients in a publication;

3. Studies in cleft lip and palate patients.

\section{Assessment of quality in studies}

A quality assessment of all the selected full-text articles was conducted. Both the exclusion process as well as the quality assessment were conducted independently by the author. Any studies that were believed to be insufficient were excluded during the process.

\section{RESULTS}

\section{Study Selection}

538 in total of related articles and abstracts were obtained from using the electronic search. During the initial screening, 420 articles were excluded. 118 articles were then completely evaluated resulting in only 53 being assesed as it fulfills the inclusion criteria of the systematic review. At the end, only 18 studies were used for assessment (Fig.1).

\section{Studies on general outcome}

\section{Studies on dental implants and implant-supported prosthetics}

6 studies in total were related to implant placement treatment for the patient. Almost all of the studies assessed were retrospective in nature.

Table 1

\begin{tabular}{|c|c|c|c|c|c|c|c|}
\hline Author & Year & Study type & Patients & Age & Treatment (maxilla) & Treatment (mandible) & Follow up [y] \\
\hline Ladda [12] & 2013 & Retrospective & 1 & 8 years old & $\begin{array}{c}\text { Complete dentures } \\
\text { Case } 1\end{array}$ & $\begin{array}{c}\text { Complete denture } \\
\text { Case } 1\end{array}$ & $\begin{array}{c}0.6 \\
\text { Case } 1\end{array}$ \\
\hline Bani [13] & 2010 & Retrospective & 2 & $\begin{array}{l}-8 \text { years old } \\
-3 \text { years old }\end{array}$ & $\begin{array}{l}\text { Complete denture } \\
\text { Case } 2 \\
\text { Complete denture }\end{array}$ & $\begin{array}{l}\text { Complete denture } \\
\text { Case } 2 \\
\text { Complete denture }\end{array}$ & $\begin{array}{c}0.3 \\
\text { Case } 2 \\
0.3\end{array}$ \\
\hline Bala [14] & 2012 & Retrospective & 1 & 7 years old & $\begin{array}{c}\text { Complete denture } \\
\text { Case } 1\end{array}$ & $\begin{array}{c}\text { Complete denture } \\
\text { Case } 1\end{array}$ & (not recorded) \\
\hline Mittal [15] & 2015 & Retrospective & 2 & $\begin{array}{l}-5 \text { years old } \\
-9 \text { years old }\end{array}$ & $\begin{array}{l}\text { Partial denture } \\
\text { Case } 2 \\
\text { Complete denture }\end{array}$ & $\begin{array}{c}\text { Complete denture } \\
\text { Case } 2 \\
\text { Implant supported overdenture }\end{array}$ & (not recorded) \\
\hline Hekmatfar [16] & 2012 & Retrospective & 2 & $\begin{array}{l}-3 \text { years old } \\
-10 \text { years old }\end{array}$ & $\begin{array}{c}\text { Case } 1 \\
\text { Complete denture } \\
\text { Case } 2 \\
\text { Partial denture }\end{array}$ & $\begin{array}{c}\text { Case } 1 \\
\text { Complete denture } \\
\text { Case } 2 \\
\text { Partial denture }\end{array}$ & $\begin{array}{c}\text { Case } 1 \\
0.6 \\
\text { Case } 2 \\
0.6\end{array}$ \\
\hline Nallanchakrava [17] & 2013 & Retrospective & 1 & 12 years old & Removable partial denture & Removable partial denture & 1.8 \\
\hline Trivedi [18] & 2013 & Retrospective & 1 & 4 years old & Partial denture & Complete denture & 0.3 \\
\hline Jain [19] & 2012 & Retrospective & 1 & 11 years old & Partial denture & Complete denture & 0.6 \\
\hline Marques [21] & 2013 & Retrospective & 1 & 5 years old & Removable partial denture & Complete denture & 1 \\
\hline Moses [22] & 2013 & Retrospective & 1 & 3 years old & $\begin{array}{c}\text { Removable partial denture } \\
\text { Case } 1\end{array}$ & $\begin{array}{c}\text { Removable partial denture } \\
\text { Case } 1\end{array}$ & $\begin{array}{c}0.3 \\
\text { Case } 1\end{array}$ \\
\hline Shigli [23] & 2012 & Retrospective & 3 & $\begin{array}{l}-10 \text { years old } \\
-9 \text { years old } \\
-9 \text { years old }\end{array}$ & $\begin{array}{c}\text { Removable partial denture } \\
\text { Case } 2 \\
\text { Removable partial denture } \\
\text { Case } 2 \\
\text { Overdenture }\end{array}$ & $\begin{array}{c}\text { Removable partial denture } \\
\text { Case } 2 \\
\text { Complete denture } \\
\text { Case } 3 \\
\text { Overdenture }\end{array}$ & $\begin{array}{c}\text { (not recorded) } \\
\text { Case } 2 \\
0.3 \\
\text { Case } 3 \\
1.5\end{array}$ \\
\hline Bala [24] & 2011 & Retrospective & 1 & 8 years old & Complete denture & Complete denture & (not recorded) \\
\hline Correia [25] & 2013 & Retrospective & 1 & 4 years old & n.a. & Removable partial denture & (not recorded) \\
\hline Bhalla [26] & 2012 & Retrospective & 1 & 6 years old & Complete denture & Complete denture & (not recorded) \\
\hline Mello [27] & 2015 & Retrospective & 1 & 9 years old & $\begin{array}{c}\text {-Implants } \\
\text {-Partial denture }\end{array}$ & $\begin{array}{c}\text {-Implants } \\
\text {-Partial denture }\end{array}$ & 0.6 \\
\hline Kramer [28] & 2006 & Retrospective & 1 & 5 years old & $\begin{array}{l}\text {-Complete denture } \\
\text {-Implants }\end{array}$ & $\begin{array}{l}\text {-Complete denture } \\
\text {-Implants }\end{array}$ & 3.0 \\
\hline Bergendal [29] & 2008 & Survey & 5 & $\begin{array}{l}-6 \text { years old } \\
-6 \text { years old } \\
-8 \text { years old } \\
-12 \text { years old } \\
-5 \text { years old }\end{array}$ & Implants & Implants & 0.6 \\
\hline
\end{tabular}

1. Case reports of patients aged 13 and above;

Eventhough the rate of survival as well as the success information is low, it was still considered for the purpose of 
synthesis of data. These studies included varying forms of implants like overdentures over implants as well as implant crowns.

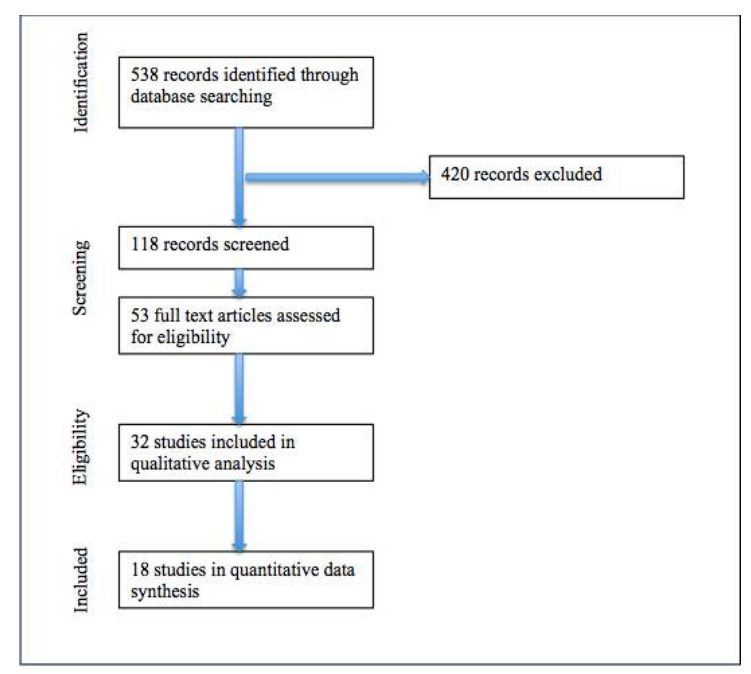

Figure 1

Based on the study by Bergendel, it was recorded that a high rate of implant failures were present in children. Since it was a survey based article, the follow-up time was not included. However, through contact with the author, it was reported that it happened during the healing process (maximum of 6 months) preceeding prosthetic restoration ${ }^{[29]}$. The study done by Mello focuses on the usage of overdentures following the placement of mini-implants. Though there were reports of implant failure on the patient, the case had a short-term follow up so further clinical evaluations should must be performed for an exact evidence on the matter. Overall, it was found that when dealing with children, the implants placed should be of a smaller size as a result of their smaller sized maxillary and cortical bones $^{[27]}$.

\section{Studies on treatment with removable partial dentures}

In young patients, the process of oral rehabilitation is the most sucessful with removable partial dentures. The reason behind this is because this treatment option helps in the improvement of the child's oral function, aesthetics as well decreases their social disadvantage. Based on the report done by Pinto, the young patient as well as his parents were onboard with the treatment since he personally felt different from his other classmates. Throughout the patients treatment, some adjustments were made to the prosthesis. The dentist did not experience any difficulty in the placement of the prosthesis. However, the partial dentures needed replacement within an average of 3-4 years because of it's short lifespan ${ }^{[20]}$.

\section{Studies on treatment with complete dentures}

Complete dentures in young children are predominantly used to help them obtain a healthy diet; especially when dealing children below the age of 3 years old. Based on case report by Bani, for the initial insertion, the patient experienced some difficulty in keeping the denture in place. However, with a few months, the patient was said to have an improvement in his speech and was pleased with the denture. This overall has helped in the maintainence of a healthy diet for the child; which was the main concern before treatment ${ }^{[13]}$.

\section{Studies on quality of life, self-esteem, and patient satisfaction}

Most of the patients satisfaction level increased only after a few months after the initial placement of the prosthetic. A large number of the patients were in a range of satisfied to very satisfied with their treatment.

\section{DISCUSSION}

The most recent information about oral treatments including outcomes were assessed in this review.

Table 2

\begin{tabular}{|c|c|c|c|}
\hline Publication & Year & Design & Outcome \\
\hline Mittal [15] & 2015 & Retrospective & $\begin{array}{c}\text { n.a. } \\
\text { Case } 2\end{array}$ \\
\hline Shigli [23] & 2012 & Retrospective & $\begin{array}{l}\text {-the facial profile as well as the expression improved with the usage of the prosthesis. Their } \\
\text { mastication and dietary patterns also improved significantly. }\end{array}$ \\
\hline Mello [27] & 2015 & Retrospective & $\begin{array}{l}\text { The patient adapted very well with the dental prosthesis. She showed great satisfaction with an } \\
\text { increase in self-esteem and an improvement in her social skills. }\end{array}$ \\
\hline Kramer [28] & 2006 & Retrospective & $\begin{array}{l}\text { The patient was easily accustomed to the prosthesis and had an excellent oral hygiene. The } \\
\text { parents reported that the patient's diet has improved and changed for the better. }\end{array}$ \\
\hline Bergendal [29] & 2008 & Cross-sectional survey & $4 / 5$ of the patients had lost at least one implant throughout the years. \\
\hline
\end{tabular}

Table 3

\begin{tabular}{|c|c|c|c|}
\hline Publication & Year & Design & Outcome \\
\hline Nallachakrava [17] & 2013 & Retrospective & $\begin{array}{l}\text { There was functional occlusion with an improvement in esthetics. The nutrition as well as their self- } \\
\text { confidence has showed an improvement. }\end{array}$ \\
\hline Hekmatfar [16] & 2012 & Retrospective & $\begin{array}{l}\text { The retention and stability of the denture was hard to obtain initially. Overall, the patients are more self- } \\
\text { confident, has improved of facial esthetics, speech as well as the mastication. }\end{array}$ \\
\hline Trivedi [18] & 2013 & Retropective & $\begin{array}{l}\text { The parents were very pleased with the outcome. There was an improvement in the patients speech and } \\
\text { esthetics that lead to a better psychological well-being. }\end{array}$ \\
\hline Jain [19] & 2012 & Retrospective & $\begin{array}{l}\text { The patient reported to be comfortable because of it's light weight quality. There was also also an } \\
\text { imrpovement in both speech and mastication. }\end{array}$ \\
\hline Pinto [20] & 2016 & Retrospective & $\begin{array}{c}\text { The child was able to experience a wider range of foods. The patient's esthetics and self-esteem also } \\
\text { improved significantly. }\end{array}$ \\
\hline Marques [21] & 2013 & Retrospective & $\begin{array}{l}\text { There were no signs of pressure points and no interferences between both dynamic and static occlusion. } \\
\text { It showed an excellent retention with an improvement in speech as well as mastication. }\end{array}$ \\
\hline Moses [22] & 2013 & Retrospective & $\begin{array}{l}\text { After intitial prosthesis insertion, the patient was depressed. After a week of usage, it became very } \\
\text { comfortable for him. Overall, his speech and masticatory function has improved significantly. }\end{array}$ \\
\hline
\end{tabular}


Table 4

\begin{tabular}{|c|c|c|c|}
\hline Publication & Year & Design & Outcome \\
\hline Ladda [12] & 2013 & Retrospective & $\begin{array}{l}\text { The patient's facial profile as well as expression has improved greatly. } \\
\text { Case } 1\end{array}$ \\
\hline Bani [13] & 2010 & Retrospective & $\begin{array}{c}\text { There was good retention and a significant improvement in both speech and mastication. The child also } \\
\text { enjoyed wearing the prosthesis. } \\
\text { Case } 2\end{array}$ \\
\hline & & & $\begin{array}{l}\text { After initial insertion of the denture, the patient was reported to have a difficult time in accepting it } \\
\text { and keeping them in the mouth. After a while, it was reported that his speech has improved. }\end{array}$ \\
\hline Bala [14] & 2012 & Retrospective & $\begin{array}{l}\text { The retention of the denture was good as the patient slowly adjusted to the prosthesis. Both his } \\
\text { aesthetics and self-esteem has improved significantly. }\end{array}$ \\
\hline Mittal [15] & 2015 & Retrospective & n.a. \\
\hline Trivedi [18] & 2013 & Retropective & $\begin{array}{l}\text { The parents were very pleased with the outcome. There was an improvement in the patients speech and } \\
\text { esthetics that lead to a better psychological well-being. }\end{array}$ \\
\hline Jain [19] & 2012 & Retrospective & $\begin{array}{l}\text { The patient reported to be comfortable because of it's light weight quality. There was also also an } \\
\text { imrpovement in both speech and mastication. }\end{array}$ \\
\hline Marques [21] & 2013 & Retrospective & $\begin{array}{l}\text { There were no signs of pressure points and no interferences between both dynamic and static occlusion. } \\
\text { It showed an excellent retention with an improvement in speech as well as mastication. }\end{array}$ \\
\hline Bala $[24]$ & 2011 & Retrospective & Both the patient's masticatory function and aesthetics has significnatly improved. \\
\hline
\end{tabular}

These studies that were assessed had a generally low quality as most of them are about removable dentures (both complete and partial) and only afew reported about implants. Eventhough the quality is low, it cannot be denied that dental implants showed a higher rate of failure with patients that have severe hypodontia when compared to healthy patients. Since this review is more focused on children that are affected with severe hypodontia, generally, removable dentures are more targeted towards them. One reason being that implants require more bone availability in the jaws and another reason being that it is a much more lower cost treatment option ${ }^{[30]}$. Generally, it is not recommended for growing children to have implants except for the interforaminal area of the mandible ${ }^{[31,32]}$. The main reason behind this is because an ongoing eruption of teeth will result in the implant submerging; similar to that of secondary retention of teeth ${ }^{[32]}$. Children on the other hand, are more easily adapted to removable partial dentures; as it can be known as their 'interim phase' ${ }^{[30]}$.

\section{CONCLUSION}

In a nutshell, the capability of deciding on a treatment for patients that have hypodontia in accordance to the evidence is not yet possible ${ }^{[30]}$. Although implant therapy for hypodontia patients have a better outcome, when dealing with children, removable partial denture is the most suitable choice.

\section{References}

1. Salinas CF, Jorgenson RJ, Wright JT, DiGiovanna JJ, Fete MD (2009). 2008 International Conference on Ectodermal Dysplasias Classification: conference report. Am J Med Genet A 149A: 1958-1969.

2. Irvine AD (2009). Towards a unified classification of the ectodermal dysplasias: opportu- nities outweigh challenges. Am J Med Genet A 149A: 1970-1972.

3. Hickey, A.J. and T.J. Vergo, Jr. 2001. Prosthetic treatments for patients with ectodermal dysplasia. J. Prosthet. Dent., 86: 364-368. World Appl. Sci. J., 20 (3): 423-428, 2012.

4. Guckes, A.D., M.S. Scurria, T.S. King, G.R. McCarthy and J.S. Brahim, 2002. Prospective clinical trial of dental implants in persons with ectodermal dysplasia. J. Prosthet Dent., 88: 21-25.
5. Tarjan, I., K. Gabris and N. Rozsa, 2005. Early prosthetic treatment of patients with ectodermal dysplasia: a clinical report. J. Prosthet Dent., 93: 419424.

6. Mikkola ML (2009). Molecular aspects of hypohidrotic ectodermal dysplasia. Am J Med Genet A 149A: 20312036.

7. Airenne P (1981). X-linked hypohidrotic ectodermal dysplasia in Finland: a clinical, radi- ographic and genetic study (Thesis). Proc Finn Dent Soc 77 Suppl.1: $1-107$.

8. Suri, S., R.P. Carmichael and B.D. Tompson, 2004. Simultaneous functional and fixed appliance therapy for growth modification and dental alignment prior to prosthetic habilitation in hypohidrotic ectodermal dysplasia: a clinical report. J. Prosthet Dent., 92: 428433.

9. Lakomski, J., K. Kobielak, A. Kobielak and W.H. Trzeciak, 1998. Correcting facial dysmorphism in a patient with anhidrotic ectodermal dysplasia: a clinical report. J. Prosthet. Dent., 80: 524-526.

10. Thilander B, Odman J, Lekholm U. Orthodontic aspects of the use of oral implants in adolescents: a 10year follow-up study. Eur J Orthod. 2001;23:715-31.

11. Ydinbelge M, Gumus HO, Sekerci AE, Demetoglu U, Etoz OA. Implants in children with hypohidrotic ectodermal dysplasia: an alternative approach to esthetic management: case report and review of the literature. Pediatr Dent 2013;35:441-446.

12. Ladda, R., Gangadhar, S., Kasat, V., \& Bhandari, A. (2013). Prosthodontic Management of Hypohidrotic Ectodermal Dysplasia with Anodontia: A Case Report in Pediatric Patient and Review of Literature. Annals of Medical and Health Sciences Research, 3(2), 277-281. http://doi.org/10.4103/2141-9248.113679

13. Bani, M., Tezkirecioglu, A. M., Akal, N., \& Tuzuner, T. (2010). Ectodermal Dysplasia with Anodontia: A Report of Two Cases. European Journal of Dentistry, 4(2), 215-222.

14. Bala, S., Nikhil, M., Chugh, A., \& Narwal, A. (2012). Prosthetic Rehabilitation of a Child Suffering from Hypohidrotic Ectodermal Dysplasia with Complete Anodontia. International Journal of Clinical Pediatric Dentistry, 5(2), 148-150. http://doi.org/10.5005/jp- 
journals-10005-1155

15. Mittal, M., Srivastava, D., Kumar, A., \& Sharma, P. (2015). Dental management of hypohidrotic ectodermal dysplasia: A report of two cases. Contemporary Clinical Dentistry, 6(3), 414-417. http://doi.org/10.4103/0976-237X.161907

16. Hekmatfar, S., Jafari, K., Meshki, R., \& Badakhsh, S. (2012). Dental Management of Ectodermal Dysplasia: Two Clinical Case Reports. Journal of Dental Research, Dental Clinics, Dental Prospects, 6(3), 108112. http://doi.org/10.5681/joddd.2012.023

17. Nallanchakrava, S. (2013). Oral Rehabilitation of a Patient with Ectodermal Dysplasia with Prosthodontics Treatment. Indian Journal of Dermatology, 58(3), 241. http://doi.org/10.4103/0019-5154.110851

18. Trivedi, B. D., \& Bhatia, R. (2013). Complete and Removable Partial Prosthesis for a Child with Hypohidrotic Ectodermal Dysplasia. International Journal of Clinical Pediatric Dentistry, 6(1), 71-74. http://doi.org/10.5005/jp-journals-10005-1192

19. Jain, N., Naitam, D., Wadkar, A., Nemane, A., Katoch, S., \& Dewangan, A. (2012). Prosthodontic Rehabilitation of Hereditary Ectodermal Dysplasia in an 11-Year-Old Patient with Flexible Denture: A Case Report. Case Reports in Dentistry, 2012, 489769. http://doi.org/10.1155/2012/489769

20. Pinto, A. S. B., Conceição Pinto, M. e S., Melo do Val, C., Costa Oliveira, L., Costa de Aquino, C., \& Vasconcelos, D. F. P. (2016). Prosthetic Management of a Child with Hypohidrotic Ectodermal Dysplasia: 6Year Follow-Up. Case Reports in Dentistry, 2016, 2164340. http://doi.org/10.1155/2016/2164340

21. Teixeira Marques, N. C., Gurgel, C. V., Fernandes, A. P., Lima, M. C., Machado, M. A. A. M., Soares, S., \& Oliveira, T. M. (2013). Prosthetic Rehabilitation in Children: An Alternative Clinical Technique. Case Reports in Dentistry, 2013, 512951. http://doi.org/10.1155/2013/512951

22. Moses, J., Gurunathan, D., Rangeeth, B. N., \& Kannan, K. . (2013). Non-Syndromic Oligodontia of Primary and Permanent Dentition: 5 Year Follow Up- A Rare Case Report. Journal of Clinical and Diagnostic Research: JCDR, 7(4), 776-779. http://doi.org/10.7860/JCDR/2013/5574.2910

23. Shigli, A., \& Airen Sarkar, P. (2012). Prosthodontic management of patients with Christ-Siemens-Touraine syndrome. BMJ Case Reports, 2012, bcr1120115226. http://doi.org/10.1136/bcr.11.2011.5226
24. Bala, M., \& Pathak, A. (2011). Ectodermal dysplasia with true anodontia. Journal of Oral and Maxillofacial Pathology: JOMFP, 15(2), 244-246. http://doi.org/10.4103/0973-029X.84515

25. Correia, M. F., Nogueira, M. N., Bedran, T. B., \& Palomari Spolidorio, D. M. (2013). Aesthetic Rehabilitation of Oligodontia in Primary Dentition with Adhesive Partial Denture. Case Reports in Dentistry, 2013, 872476. http://doi.org/10.1155/2013/872476

26. Bhalla, G., Agrawal, K. K., Singh, K., Singh, B. P., \& Goel, P. (2013). A Preliminary Study to Analyze the Cranio-facial Growth of an Ectodermal Dysplasia Patient After Prosthetic Rehabilitation. The Journal of the Indian Prosthodontic Society, 13(1), 43-48. http://doi.org/10.1007/s13191-012-0167-0

27. Mello, Bianca Zeponi Fernandes, Silva, Thiago Cruvinel, Rios, Daniela, Machado, Maria Aparecida Andrade Moreira, Valarelli, Fabrício Pinelli, \& Oliveira, Thais Marchini. (2015). Mini-implants: Alternative for Oral Rehabilitation of a Child with Ectodermal Dysplasia. Brazilian Dental Journal, 26(1), 75-78. https:// dx.doi.org/ 10.1590/ 01036440201300111

28. Kramer F-J, Baethge C, Tschernitschek H. Implants in children with ectodermal dysplasia: a case report and literature review. Clin. Oral Impl. Res. 18, 2007; 140146 doi: 10.1111/j.1600-0501.2006.01180.x

29. Bergendal B, Ekman A, Nilsson P. Implant failure in young children with ectodermal dysplasia: a retrospective evaluation of use and outcome of dental implant treatment in children in Sweden. Int J Oral Maxillofac Implants. 2008;23:520-4.

30. Filius, M. A., Cune, M. S., Raghoebar, G. M., Vissink, A. and Visser, A. (2016), Prosthetic treatment outcome in patients with severe hypodontia: a systematic review. $J$ Oral Rehabil, 43: 373-387. doi:10.1111/joor.12384

31. Sweeney IP, Ferguson JW, Heggie AA, Lucas JO. Treatment outcomes for adolescent ectodermal dysplasia patients treated with dental implants. Int $J$ Paediatr Dent. 2005;15:241-248.

32. Kearns G, Sharma A, Perrott D, Schmidt B, Kaban L, Vargervik K. Placement of endosseous implants in children and adolescents with hereditary ectodermal dysplasia. Oral Surg Oral Med Oral Pathol Oral Radiol Endod. 1999;88: 5-10.

\section{Please cite this article in press as:}

Nur Qistina Binti Ahmad Fauzi., Ashok and Dhanraj (2017), 'A Systematic Review: The Prevelance Of Partial Edentulourism In Patients With Ectodermal Dysplasia', International Journal of Current Advanced Research, 6(3), pp. $2987-2991$.

http://dx.doi.org/10.24327/ijcar.2017. 2991.0161 